Article

\title{
Encapsulating TGF- $\beta 1$ Inhibitory Peptides P17 and P144 as a Promising Strategy to Facilitate Their Dissolution and to Improve Their Functionalization
}

\author{
Nemany A. N. Hanafy ${ }^{1, *(\mathbb{D}}$, Isabel Fabregat ${ }^{2}{ }^{\mathbb{C}}$, Stefano Leporatti ${ }^{3, *(\mathbb{D})}$ and Maged El Kemary ${ }^{1}$ \\ 1 Nanomedicine Department, Institute of Nanoscience and Nanotechnology, Kafrelsheikh University, \\ Kafrelsheikh 33516, Egypt; elkemary@yahoo.com \\ 2 Bellvitge Biomedical Research Institute (IDIBELL), University of Barcelona (UB) and CIBEREHD, Gran Via \\ de l'Hospitalet, 199, Hospitalet de Llobregat, 08908 Barcelona, Spain; ifabregat@idibell.cat \\ 3 CNR NANOTEC-Istituto di Nanotecnologia, Via Monteroni, 73100 Lecce, Italy \\ * Correspondence: nemany.hanafy@nano.kfs.edu.eg (N.A.N.H.); stefano.leporatti@nanotec.cnr.it (S.L.)
}

Received: 24 March 2020; Accepted: 29 April 2020; Published: 2 May 2020

\begin{abstract}
Transforming growth factor-beta (TGF $\beta 1$ ) is considered as a master regulator for many intracellular signaling pathways, including proliferation, differentiation and death, both in health and disease. It further represents an oncogenic factor in advanced tumors allowing cancer cells to be more invasive and prone to move into the metastatic process. This finding has received great attention for discovering new therapeutic molecules against the TGF $\beta 1$ pathway. Among many TGF $\beta 1$ inhibitors, peptides (P17 and P144) were designed to block the TGF $\beta 1$ pathway. However, their therapeutic applications have limited use, due to lack of selection for their targets and their possible recognition by the immune system and further due to their potential cytotoxicity on healthy cells. Besides that, P144 is a highly hydrophobic molecule with less dissolution even in organic solution. Here, we aimed to overcome the dissolution of P144, as well as design nano-delivery strategies to protect normal cells, to increase cellular penetration and to raise the targeted therapy of both P17 and P144. Peptides were encapsulated in moieties of polymer hybrid protein. Their assembly was investigated by TEM, microplate spectrum analysis and fluorescence microscopy. SMAD phosphorylation was analyzed by Western blot as a hallmark of their biological efficiency. The results showed that the encapsulation of P17 and P144 might improve their potential therapeutic applications.
\end{abstract}

Keywords: transforming growth factors; proliferation; polymer hybrid protein

\section{Introduction}

Transforming growth factor (TGF $\beta$ ) is a secreted cytokine, having the ability to regulate and control cell proliferation, migration, differentiation and cytoskeleton morphology [1-3]. Apart from this fact, the role of TGF $\beta$ in controlling inflammation, wound healing and tissue repair received a lot of interest [4]. However, its function as a tumor promoter at the end stage of cancer development resulted in an impact issue, since it supports cancer growth, activates tumor angiogenesis and inhibits immune responses [5-7]. Among many molecules that were used to inhibit TGF $\beta$ signaling pathway, TGF $\beta$ inhibitory peptides have obtained great interest due to their efficient role in blocking of TGF $\beta$ signaling pathways [8]. Peptide P144, TSLDASIIWAMMQN, is a very hydrophobic peptide obtained from the membrane-proximal ligand-binding domain of b-glycan [9]. This peptide is designed to block TGF $\beta R$ III extracellular domains preventing cellular interaction between TGF ligand and its receptors [10]. Another soluble peptide is called P17, (KRIWFIPRSSWYERA) [11]. It was produced from a phage library [12]. P17 can block TGF- $\beta 1$, TGF $\beta 2$ and TGF $\beta 3$ with relative affinity binding reached $100 \%$, $80 \%$ and $30 \%$ respectively [13]. The active inhibitory effect of both peptides was characterized in vivo 
and in vitro for several models of fibrosis and scleroderma [14]. Results have proven the potential therapeutic value for both peptides to block the TGF $\beta$ pathway and to prevent the accumulation of collagen fibers [15]. However, there is an urgent needing strategy to improve their dissolution, prevent their aggregation and facilitate their delivery into animal models. P144 was used previously either after it is suspended inside dimethyl sulfoxide (DMSO)-saline [16] or, after its integration into the composition of the lipogel in the presence of 5\% DMSO [17]. Both strategies were restricted due to the presence of DMSO [18]. Additionally, both peptides can be distributed into the whole body, with no specific delivery into a certain region. Leading to increase their accumulation inside healthy tissues. Additionally, due to their amino acid structure, they can be recognized in the bloodstream and then can be engulfed by the immune system or can be degraded inside the stomach by a biological enzyme [19]. In the current study, the sonicated P144 and suspended P17 were internalized into the bovine serum albumin matrix through amino-carboxyl interaction. Such attachment is characterized by strong interaction between peptide and protein due to the presence of carboxyl, amino-groups and hydrogen intermolecular interactions.

Additionally, the surface of the protein-peptide complex was further functionalized by folic-acid-attached carboxymethyl cellulose (CMC; Supplementary Scheme S1A). Folic acid is used as a ligand and can bind folate receptors. Additionally, CMC has mucoadhesive properties and allows protein-peptide formulation to adhere and penetrate mucus layers. This strategy provides a novel and concrete reason to strengthen the potential application of peptides as a targeted delivery. The efficiency of encapsulated peptides (P144 and P17) and the pure peptides (with no addition of DMSO or integration into lipogel) were studied by using two different hepatocellular carcinomas (HCC) cell lines: hepatitis B-positive SNU449 cells, [20], that were characterized by a mesenchymal phenotype expression [21] and the human epithelial HCC Hep3B cells [22] with different genetic characterization.

\section{Materials and Methods}

\subsection{Chemicals}

The suppliers of the chemicals were as follows. Carboxy methylcellulose (CMC) was purchased from Fluka, Sigma-Aldrich (St. Louis, MO, USA), phosphate-buffered saline (PBS) tablets of pH 7.3 were purchased from Oxoid Limited Basingstoke (Hampshire, England); ethanol from Baker Analyzed, Fisher Scientific, (Landsmeer, The Netherlands); bovine serum albumin (BSA), folic acid (FA), crystal violet, 40,6-diamidino-2-phenylindole dihydrochloride (DAPI), paraformaldehyde, N-ethyl-N0- (3 dimethylaminopropyl)carbodiimide hydrochloride (EDAC), N-hydroxy succinimide (NHS), dimethyl sulfoxide (DMSO) from Sigma-Aldrich (St. Louis, MO, USA).

\subsection{Fabrication of Protein-Peptide Mucoadhesive Carriers}

A $1 \mathrm{mg}$ amount of sonicated P144 and suspended P17 was mixed into BSA solution ( $50 \mu \mathrm{g} / 50 \mathrm{~mL})$. Then, the mixture will be grafted by carboxymethyl cellulose inside sterilized glass vials for $30 \mathrm{~min}$ under rotation by a magnetic stirrer in the presence of EDAC/NHS. The complex was further coated by $5 \mathrm{~mL}$ of $50 \mu \mathrm{g} / 50 \mathrm{~mL}$ protamine and the stirrer was continued into addition for $10 \mathrm{~min}$. Afterward, the mixture was furthermore covered by folic-acid-attached carboxymethyl cellulose and the rotation was completed in an additional $15 \mathrm{~min}$. Un-reacted materials were removed by using a dialysis bag against distilled water for $48 \mathrm{~h}$. The water was changed several times. Then, the final product was lyophilized at a freeze-drying machine while the material was kept at $-20^{\circ} \mathrm{C}$ until use.

\subsection{Characterization of the Protein-Peptides Mucoadhesive Formulation}

\subsubsection{Transmission Electron Microscopy (TEM)}

A $10 \mu \mathrm{L}$ volume of nanoparticle suspension was deposited on the copper grid and air-dried before measurement. Copper grids sputtered with carbon films were used to support the sample. 
High-resolution TEM images of nanoparticles were analyzed by a Hitachi HT 7700 operating (Hitachi, Japan) at 100 kV, coupled with a GATAN camera ORIUS SC600 (Gatan, Inc., Pleasanton, CA, USA)) with a resolution of 7 megapixels. The GATAN camera is controlled by Digital Micrograph (Gatan, Inc., Pleasanton, CA, USA) [23]

\subsubsection{UV-Vis Spectroscopy}

The absorbance of folic acid and rhodamine was measured by using a multiplate reader at the option of UV Absorbance Spectrophotometer in multiplate wells. A $500 \mu \mathrm{L} \mathrm{mL}$ volume of fabricated nanoparticles was scanned at a range of 300-600 nm [24].

\subsubsection{Zeta Potential}

The electrophoretic mobility of samples was determined by photon correlation spectroscopy by using a Zeta Nano Sizer (Malvern Instruments, Malvern, UK). All measurements were performed at 25 ${ }^{\circ} \mathrm{C}$. Five following measurements were taken for analysis; each was run five times with a delay of $5 \mathrm{~s}$ after each measurement [25].

\subsubsection{ImageJ Analysis and Calculation of the Surface Roughness}

The measurements for the light microscopic images $(400 \mu \mathrm{m})$ were carried out in pixels. Thus, setting up a scale bar for calibration for the calculation of the actual area was not required. Since, in the "Image" option of ImageJ, under Adjust, "size" was selected. Then, the pixel of width and length was adjusted and it is followed by using the "Surface Plot" option in "Analyze". This led to the area measurement of the complete image in pixels.

The measured peaks upon the material surface expressed the status of material that was either roughness or granules, while no peaks were measured in the case of soft materials or those that did not contain any granulated materials [26].

\subsection{Cell Culture}

Hep3B and SNU449 cells were obtained from the European Collection of Cell Cultures (ECACC). Cell lines were never used in the laboratory for longer than 4 months after receipt or resuscitation. All cells were maintained in DMEM media (Lonza, Basel, Switzerland) supplemented with 10\% FBS (Sera Laboratories International Ltd., West Sussex, UK), penicillin (100 U/mL), streptomycin $(100 \mu \mathrm{g} / \mathrm{mL})$, amphotericin $(2.5 \mu \mathrm{g} / \mathrm{mL})$ and L-glutamine $(2 \mathrm{mM})$. They were maintained in a humidified atmosphere at $37^{\circ} \mathrm{C}$ and $5 \% \mathrm{CO}_{2}$. Cells were observed under an Olympus IX-70 microscope.

\subsubsection{Cellular Uptake}

Ten thousand human liver cancer cell lines were seeded upon the surface of a sterilized cover slip that was laid in the bottom of 6 multi-well microplates. After $24 \mathrm{~h}$ from their growth, encapsulated peptides and non-encapsulated $(50 \mu \mathrm{g} / \mathrm{mL})$ were added to each well and incubated in a humidified atmosphere of $37{ }^{\circ} \mathrm{C}, 5 \% \mathrm{CO}_{2}$. SNU449 and Hep3B cell lines were fixed by $4 \%$ paraformaldehyde then washed by PBS (phosphate-buffered saline) at pH 7.2. Cells were then stained by DAPI (nuclear stain) for $30 \mathrm{~min}$ and washed twice by PBS,7.2. Cellular uptake was analyzed after $24 \mathrm{~h}$ by red (TRITC), green (FITC) and blue (DAPI) channels of fluorescence microscopy. After that, images were captured by fluorescence microscopy with a digital camera $[27,28]$.

\subsubsection{Proliferation Assay}

To evaluate cell proliferation, crystal violet assay was performed at 3, 6, 12, 24, 48 and $72 \mathrm{~h}$ [29]. Briefly, $7 \times 10^{3}$ cells/well were seeded in 96-well flat-bottom plates and allowed to grow for $24 \mathrm{~h}$. Encapsulated peptides (P17 and P144) and free capsules were then added at different concentrations $(10,50,100,200 \mu \mathrm{g} / \mathrm{mL})$. After incubation for a certain time, DMEM media was removed and cells were 
washed using PBS 3 times. Cells were then fixed for $10 \mathrm{~min}$ in a solution of buffered formalin $(3.7 \%)$, and then cells were washed with PBS ( $\mathrm{pH} 7.3$ ) and subsequently stained with a $0.01 \%$ crystal violet solution. After removing excess stain, the crystal violet stained cells were dissolved in $1 \mathrm{~mL}$ of a $10 \%$ sodium dodecyl sulfate solution for $2 \mathrm{~h}$ under orbital shaking and the optical density of the extracted dye was read with a spectrophotometer at $590 \mathrm{~nm}$. Optical density measurements give an indication of the relative number of viable cells present at the time of adding dye and this is used to create survival curves. Cell survival at each dose point was expressed as a percentage of the control survival rate.

\subsubsection{Western Blot Analysis}

Total protein extracts were obtained as described previously [30], separated by SDS/PAGE (12\% polyacrylamide gels) and transferred on to PVDF membranes. After blocking with $5 \%(w / v)$ non-fat milk TBST (Tris-buffered saline solution containing 0.05\% (v/v) Tween 20), the membranes were incubated overnight with the corresponding antibody in a 0.5\% non-fat milk TBST (diluted 1:5000 for $\beta$-actin and 1:1000 for all others). After washing and incubating the membrane with an appropriate peroxidase-conjugated antibody (diluted 1:5000) for $1 \mathrm{~h}$ at $21^{\circ} \mathrm{C}$, antibody binding was revealed using ECL $^{\circledR}$ (GE-Healthcare). $\beta$-actin was used as a loading control.

\subsection{Ethical Approval}

All experiments were conducted in accordance with US National Institutes of Health Guidelines for the Care and Use of Laboratory Animals and cell line experiments Guide for the Care and Use of Laboratory Animals after being approved by the relevant Ethical Committee and authorized by the Italian and German Ministry of Health. This study was also approved by the Research Ethics Committee of Kafrelsheikh University.

\section{Results}

\subsection{Physical Properties of Peptide P17 and P144}

P144 is a very hydrophobic peptide, has a limited dissolution either inside aqueous solution or even in an organic solvent such as DMSO (Figure 1A,B) [10]. This drawback leads to a reduction of its delivery into preclinical studies and minimizes its potential applications. The dissolution of bulk P144 was obtained by using physical sonication for $15 \mathrm{~min}$ under high amplitude to prevent microscopic bubbles in solution. After sonication, the bulk of P144 was separated into a colloidal suspension containing small peptide particles (Figure $1 \mathrm{C}, \mathrm{D}$ ). However, these small particles turned into aggregation after their precipitation (Figure 1G). The bulk of P144 is formed by tiny small molecules held together by electrostatic force. These small particles had lost their ionic balance after their separation. For this reason, the separated particles of P144 tend to bind back forming an aggregated state. Contrarily, P17 is very soluble in water, forming a colloidal suspension with good stability [11]. Meanwhile, P17 has a widescreen attachment with three TGF $\beta$ isoforms such as TGF $\beta 1$, TGF $\beta 2$ and TGF $\beta 3$.

To investigate their properties with fluorophore conjugation and to follow their cellular uptake, the anti-TGF $\beta$ inhibitory peptides (P17 and P144) were labeled by rhodamine (RG6; Figure 1G) [31]. Rhodamine-labeled peptides showed strong absorbance at $550 \mathrm{~nm}$ associated with a peak of pure rhodamine [32]. Their interaction is attributed to the amino group of rhodamine and the carboxyl group of peptides. It is noticed that rhodamine-doped peptides have a strengthened second peak localized at $490 \mathrm{~nm}$. This peak emitted green fluorescence with fluorescence microscopy (Figure 1G,H). In addition, sonicated P144 and dissolved P17 were shown as aggregated peptides even after their cellular uptake (Figure 1H). 

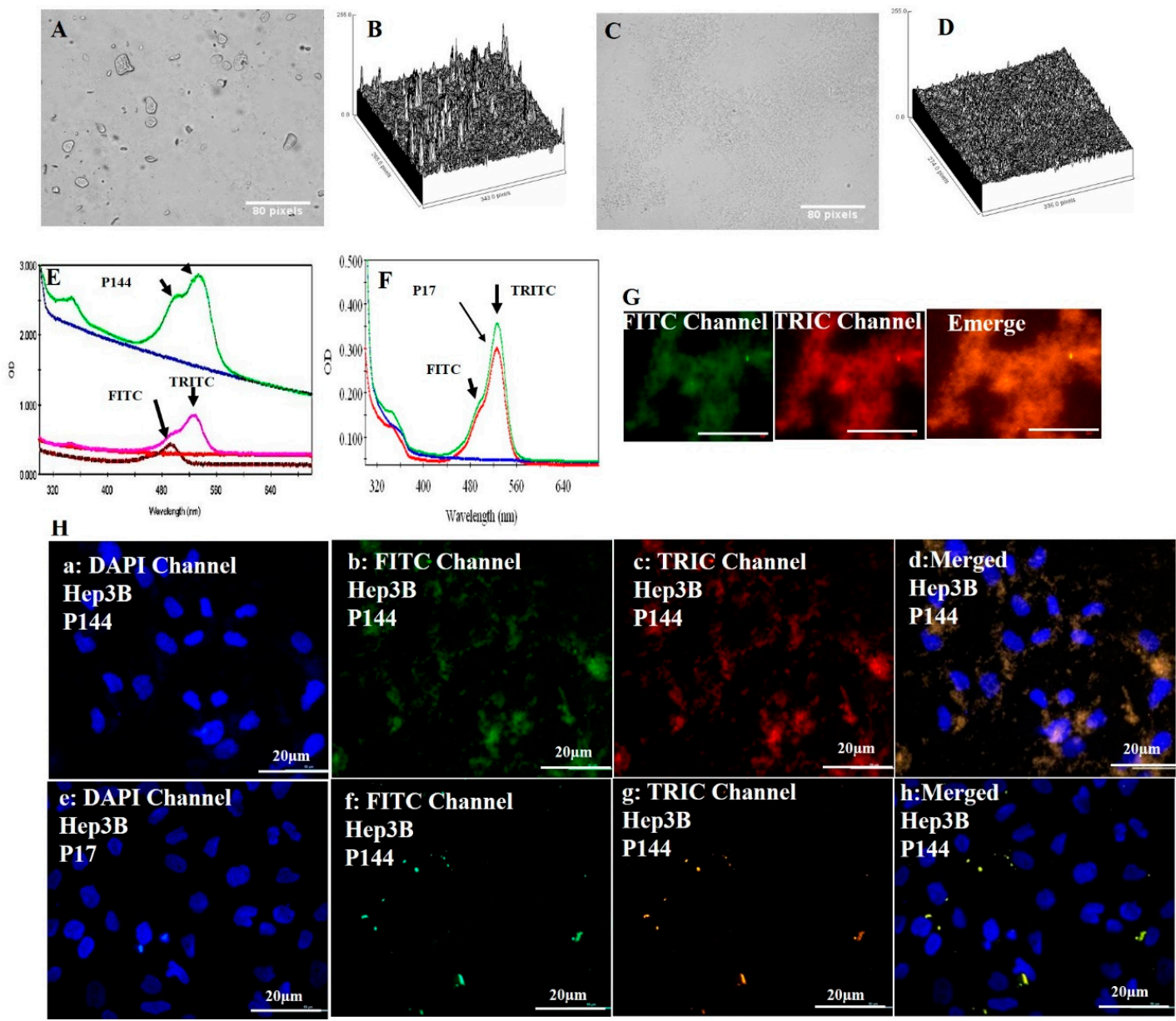

Figure 1. Optical microscopic image of P144 dissolution. (A) P144 dissolved by DMSO; (B) ImageJ analysis of P144 dissolved by DMSO; (C) P144 dissolved by sonication; (D) ImageJ analysis of sonicated P144; (E) rhodamine-labeled peptide P144; (F) rhodamine-labeled peptide P17; (G) fluorescence microscopy for images labeled P144. (H; a-d) Cellular uptake of sonicated P144; (E-H) Cellular uptake of suspended P17.

\subsection{Fabrication of Protein-Peptide Mucoadhesive Complex}

Both peptides (P17 and 144) were suspended in PBS at pH 7.2 and then P144 was sonicated by ultrasonicator. The processing time was adjusted for $15 \mathrm{~min}$ under amplitude five (intensity). The processing time is further divided into three steps each one has taken $5 \mathrm{~min}$. Under magnetic stirrer, the sonicated P144 and suspended P17 were then integrated into BSA moieties in the presence of carbodiimide and n-hydroxy succinimide [33]. The reaction was continued by completing the stirrer for $15 \mathrm{~min}$ and then carboxymethyl cellulose was added and the stirring was further continued into addition for $10 \mathrm{~min}$. Free capsules (with no encapsulated peptides) were labeled by fluorescence isothiocyanate (Figure 5 and Supplementary Scheme S1B). Both formulations were then functionalized by adding protamine to observe helix structure [34]. Indeed, protamine can modify the size of particles without any restriction for moieties of the protein-peptide complex. These results showed good turbidity after using protamine due to the presence of arginine (Figure 2A,B) [34]. Peptide protein mucoadhesive nanoparticles exhibit unaggregated and rounded core-shell assembly (Figure 2C-E) and have Z-potential value ( $-25 \mathrm{mV}$; Figure 3$)$. This indicates good physical stability of nanosuspensions due to electrostatic repulsion of individual particles. Additionally, folic acid doped carboxymethyl cellulose was added as the last layer to the formulation. This may strengthen the properties of mucoadhesive targeting therapy (Figure 2F,G and Supplementary Scheme S1A). Indeed, this strategy was designed by using two layers from $\mathrm{CMC}$, one is integrated into the middle layer and the second is 
added as the last layer. Therefore, this mechanism allows facilitating cellular adhesion and penetration, leading to increased stability of peptides in aqueous solution and improved cellular uptake for both peptides (P144 and P17; Supplementary Scheme S2).
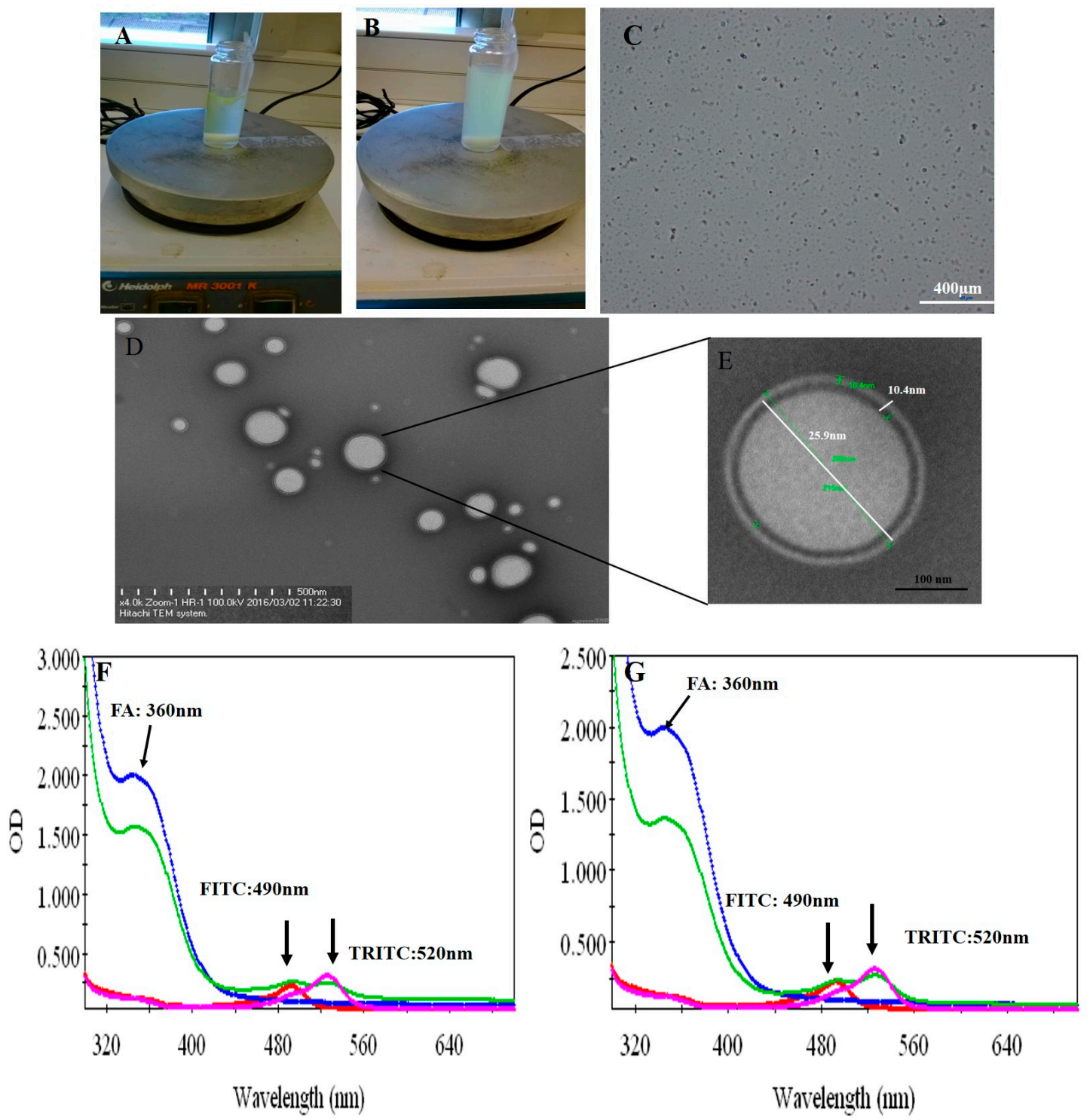

Figure 2. Fabrication of protein-peptide mucoadhesive complex. (A) Peptide conjugated protein; (B) turbid suspension after adding protamine. (C) Optical microscopic image reporting a homogenous distribution of particles. (D) Protein-peptide mucoadhesive complex TEM image. (E) TEM at high magnification. (F) UV-visible absorbance of P17. (G) UV-visible absorbance of P144. 


$\begin{array}{rllll} & & \text { Mean }(\mathbf{m V}) & \text { Area }(\%) & \text { Width }(\mathbf{m V}) \\ \text { Zeta Potential }(\mathbf{m V}):-25,7 & \text { Peak 1: } & -25,7 & 100,0 & 5,01 \\ \text { Zeta Deviation }(\mathbf{m V}): 5,01 & \text { Peak 2: } & 0,00 & 0,0 & 0,00 \\ \text { Conductivity }(\mathbf{m S} / \mathrm{cm}): 0,0110 & \text { Peak 3: } 0,00 & 0,0 & 0,00 \\ \text { Result quality : Good } & & & & \end{array}$

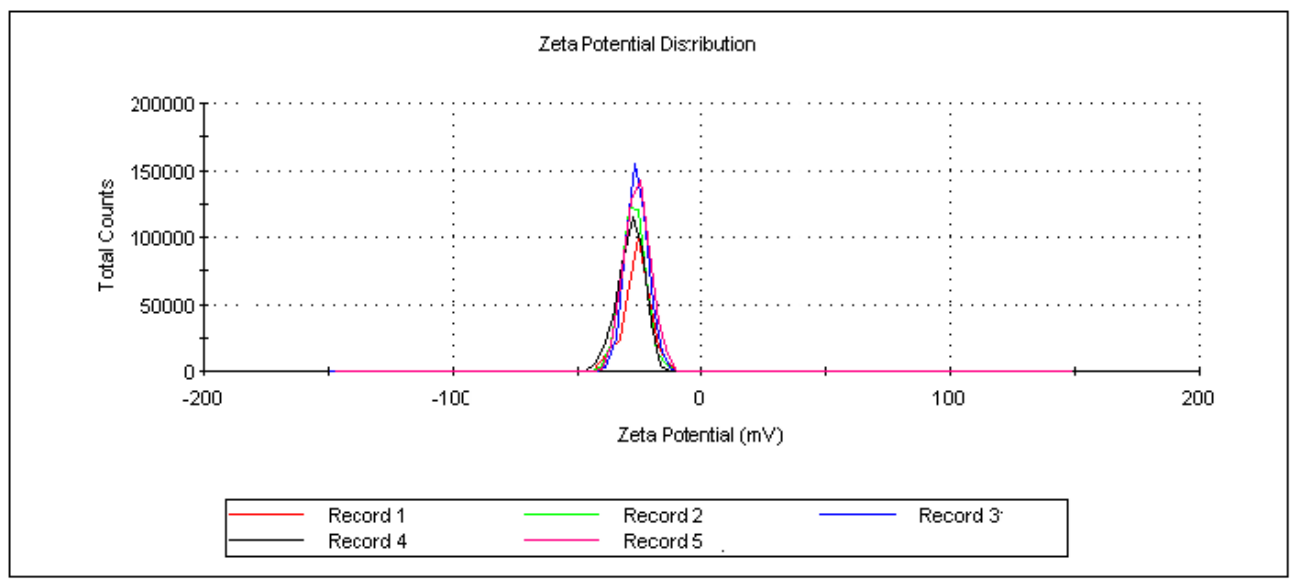

Figure 3. Zeta potential measurement after five successful running data. Each one was run five times with a delay of $5 \mathrm{~s}$ after each measurement.

\subsection{Biological Experiments: Cellular Uptake}

The rhodamine-labeled non-encapsulated peptides were accumulated successfully inside the cytoplasm as shown by fluorescent emission of TRITC channel (red spots). On the other hand, the green color was shown by using the FITC channel, indicating that peptides are able to emit green intensity after their doping with R6G (Figure 1G,H). Similarly, encapsulated peptides that were labeled by rhodamine showed good intensity for both TRITC and FITC channels after their cellular internalization as well (Figure $4 \mathrm{~A}-\mathrm{P}$ ). Indeed, the labeled peptides were accumulated around the perinuclear region of both Hep3B and SNU449 cell lines. Such emissions are mostly related to the presence of tryptophan, tyrosine and phenylalanine. While in the presence of rhodamine, the fluorescent signal is strengthened and intensity is increased. It is reported that tryptophan is highly sensitive to hydrogen bonding and non-covalent interactions, displaying a red, green and blue shift [35]. Additionally, its indole group is considered the dominant source of UV absorbance at $\sim 280 \mathrm{~nm}$ and emission at $\sim 350 \mathrm{~nm}$ [36].

The results indicate that there is a good distribution of adsorbed peptides inside cytoplasm after their encapsulation compared to those used with no encapsulation. Similarly, free capsules were localized inside cytoplasm after their cellular adsorption (Figure 5). On the contrary, the non-encapsulated peptides accumulated in an aggregated state even after their cellular uptake (Figure $1 \mathrm{H}$ (merged)). This perhaps explains that the separation of P144 bulk into small particles by using physical sonication is not really enough to keep these particles separately because these particles tend to bind back after their accumulation. 


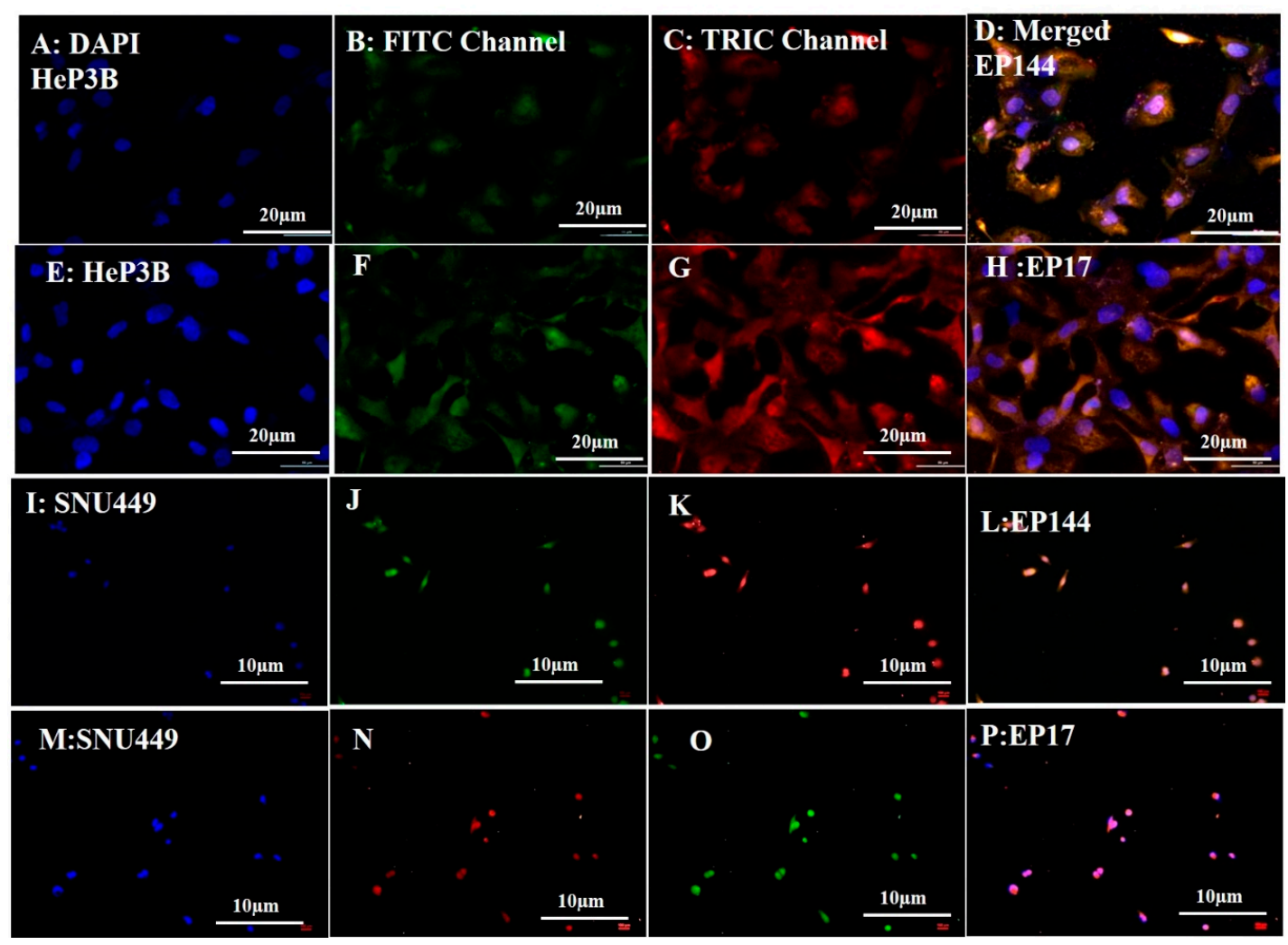

Figure 4. Fluorescence images of cellular uptake (A-D) Hep3B adsorbed EP144. (E-H) Hep3B adsorbed EP17. (I-L) SNU449-adsorbed EP144. (M-P) SNU449-adsorbed EP17.

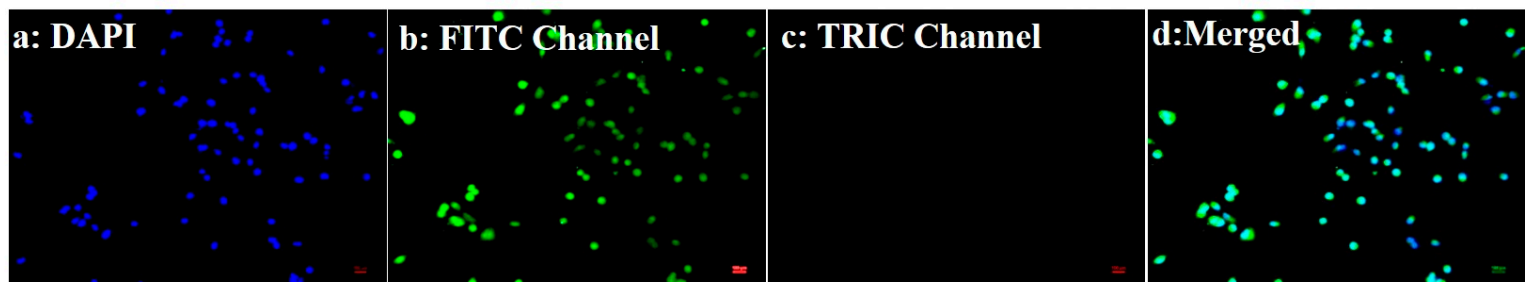

Figure 5. Fluorescence images of cellular uptake. SNU449-adsorbed free capsules.

\subsection{Determination of Nuclear Morphology by Using DAPI Staining}

DAPI (4', 6-diamidino-2-phenylindole) is a specific fluorophore for a nucleic acid because it is able to bind preferentially to adenine thymine base pair and also to phosphate groups of DNA [37-40]. This mechanism allows researchers to discover the alteration associated with nuclear morphology. In the current study, DAPI staining indicates that there are no changes in nuclear morphology for cells SNU449 after their exposure to $50 \mu \mathrm{g} / \mathrm{mL}$ free capsules (empty vehicles) with no encapsulated peptides for $24 \mathrm{~h}$ (Figure 6). However, there are clear alterations for nuclear morphology in both cell lines Hep3B and SNU449 after their exposure to encapsulated P17 and P144 for $24 \mathrm{~h}$. Results showed that there was an increasing number of condensed nuclei, nuclear fragmentation and hypotrophy [41-43]. Additionally, their morphology suffered from phenotype alteration (Figure 7, Part 1 and Part 2). 

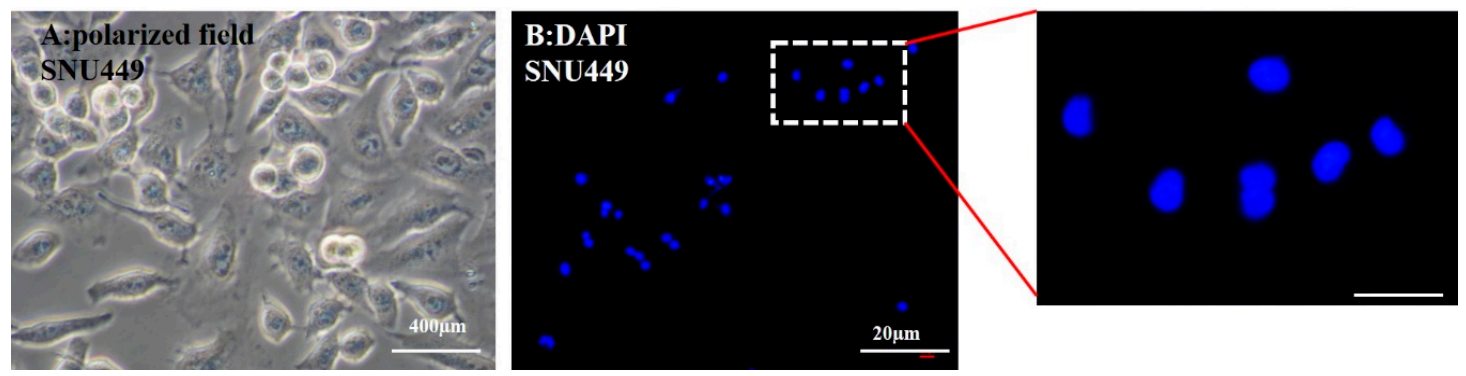

Figure 6. (A) Optical microscopy image of SNU449 after their exposure to $50 \mu \mathrm{g} / \mathrm{mL}$ free capsules for $24 \mathrm{~h}$ of incubation. (B) Fluorescence image of DAPI staining.

\section{Part:1}

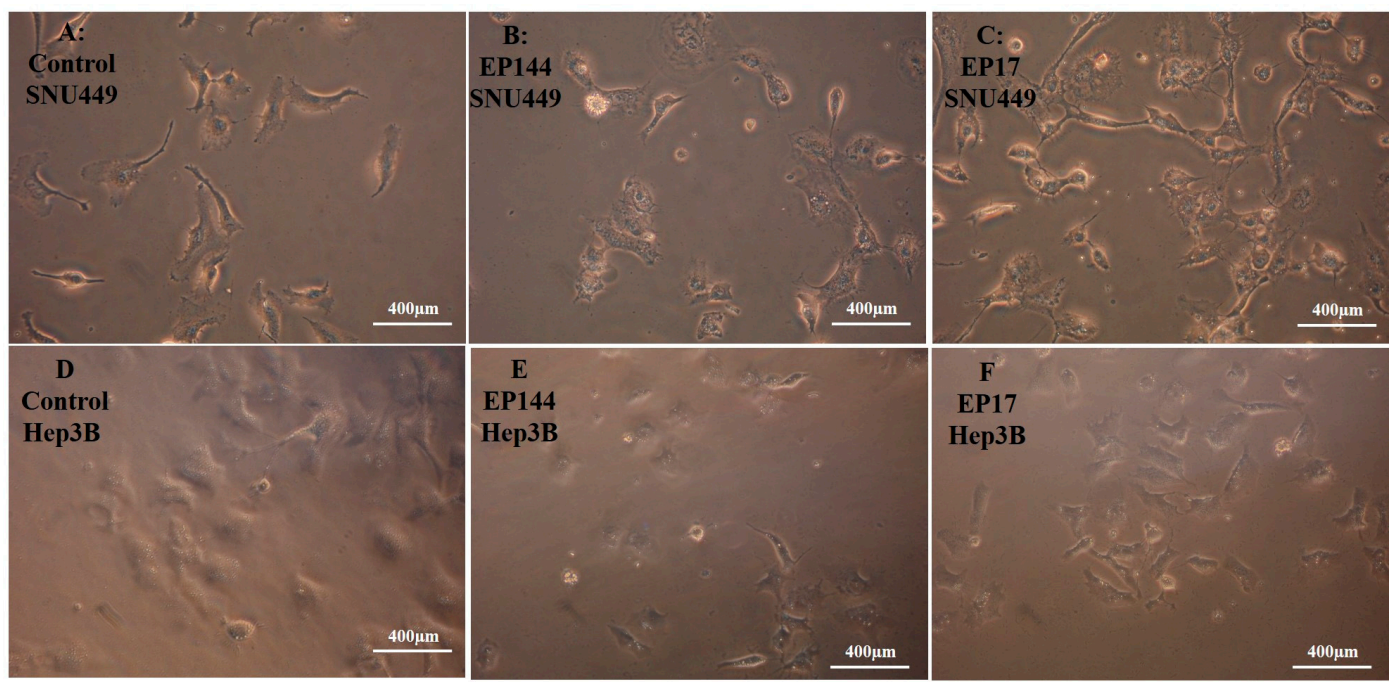

Part:2
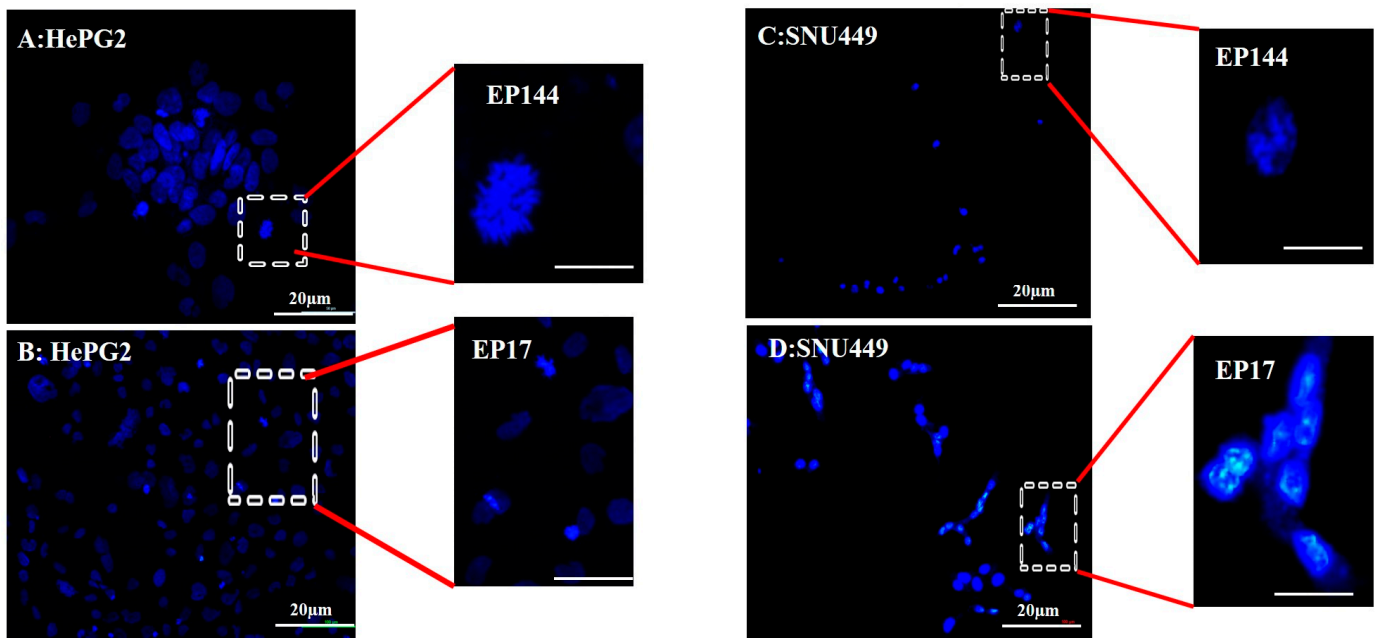

Figure 7. (Part 1) SNU449 and Hep3B cell lines suffered from phenotype changes. (A) control SNU449. (B) SNU449 exposed to $50 \mu \mathrm{g} / \mathrm{mL}$ EP144. (C)SNU449 exposed to $50 \mu \mathrm{g} / \mathrm{mL}$ EP17. (D) control Hep3B. (E) Hep3B exposed to $50 \mu \mathrm{g} / \mathrm{mL}$ EP144. (F) Hep3B exposed to $50 \mu \mathrm{g} / \mathrm{mL}$ EP17. (Part 2) Fluorescence images of morphology of DAPI staining (A) Nuclear degradation at Hep3B. (B) Nuclear condensation at Hep3B. (C) Nuclear fragmentation at SNU449. (D) Nuclear activation at SNU449.

On the contrary, the Hep3B and SNU449 exposed to non-encapsulated peptides exhibited no more changes in their morphology. However, a slightly condensed nucleation was shown (Figure 8, Part 1 and Part 2). Additionally, quantitative analysis of nuclear morphology indicates that Hep3B 
and SNU449 cells that were exposed to encapsulated peptides (P17 and P144) exhibited significantly nuclear alterations compared to non-encapsulated peptides (Figure 9).

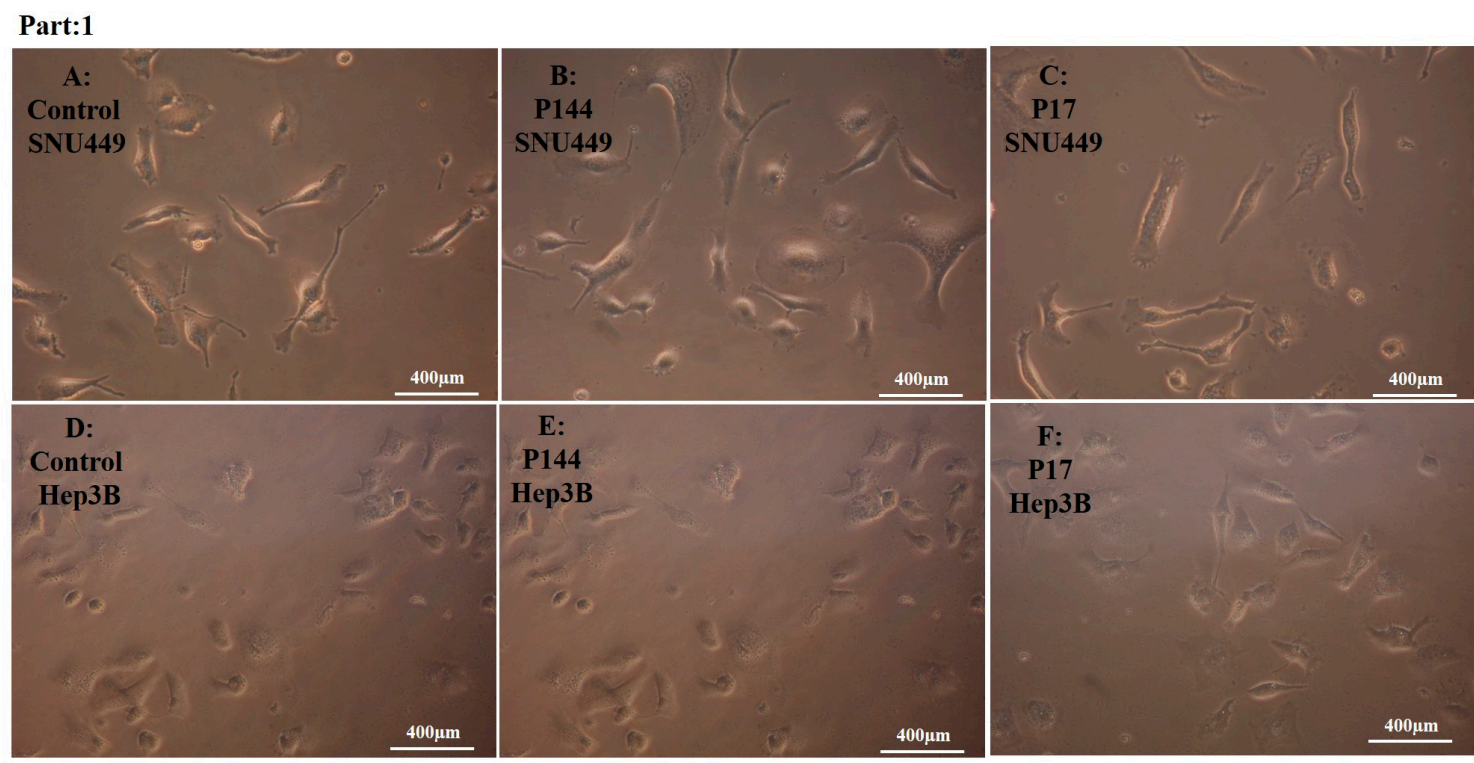

Part:2
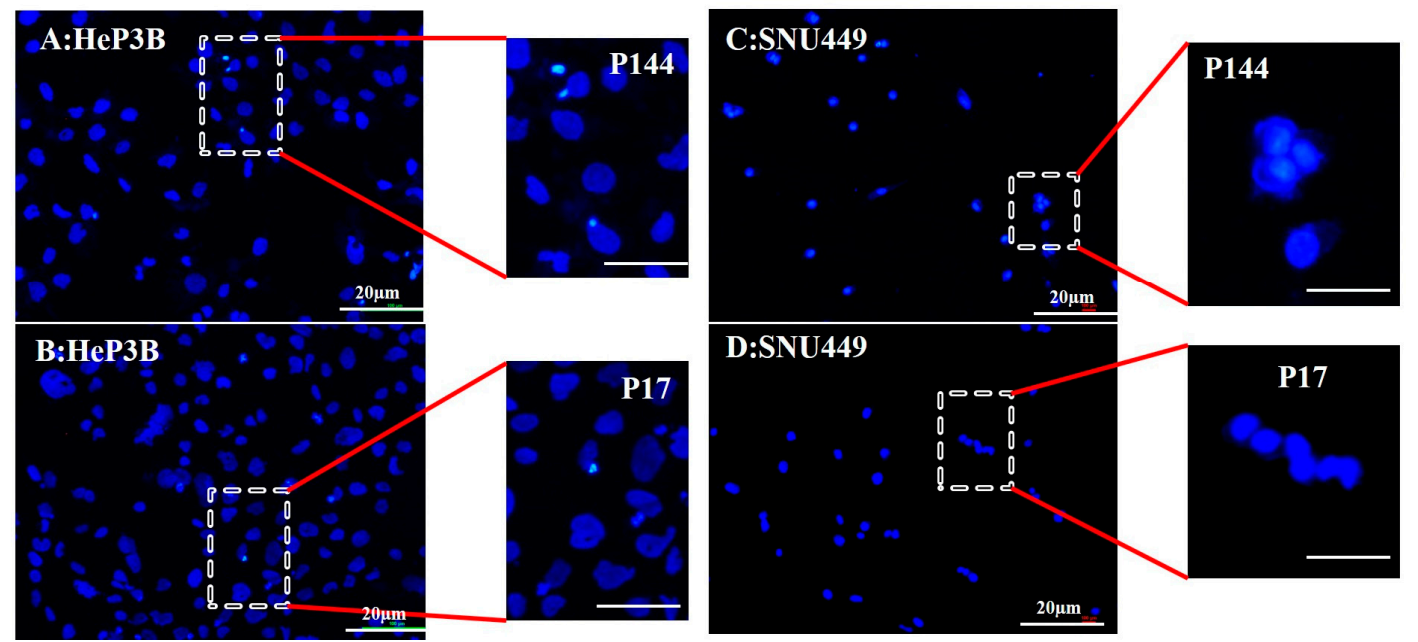

Figure 8. (Part 1) Optical microscopy images SNU449 and Hep3B cell lines suffered from phenotype changes. (A) control SNU449. (B) SNU449 exposed to $50 \mu \mathrm{g} / \mathrm{mL}$ P144. (C) SNU449 exposed to $50 \mu \mathrm{g} / \mathrm{mL}$ P17. (D) control Hep3B. (E) Hep3B exposed to $50 \mu \mathrm{g} / \mathrm{mL}$ P144. (F) Hep3B exposed to $50 \mu \mathrm{g} / \mathrm{mL}$ P17. (Part 2) Fluorescence images of the morphology of DAPI staining; (A) Slightly nuclear condensation at Hep3B. (B) Few nuclear condensations. (C) Slightly nuclear activation at SNU449. (D) No morphological alteration at SNU449. 

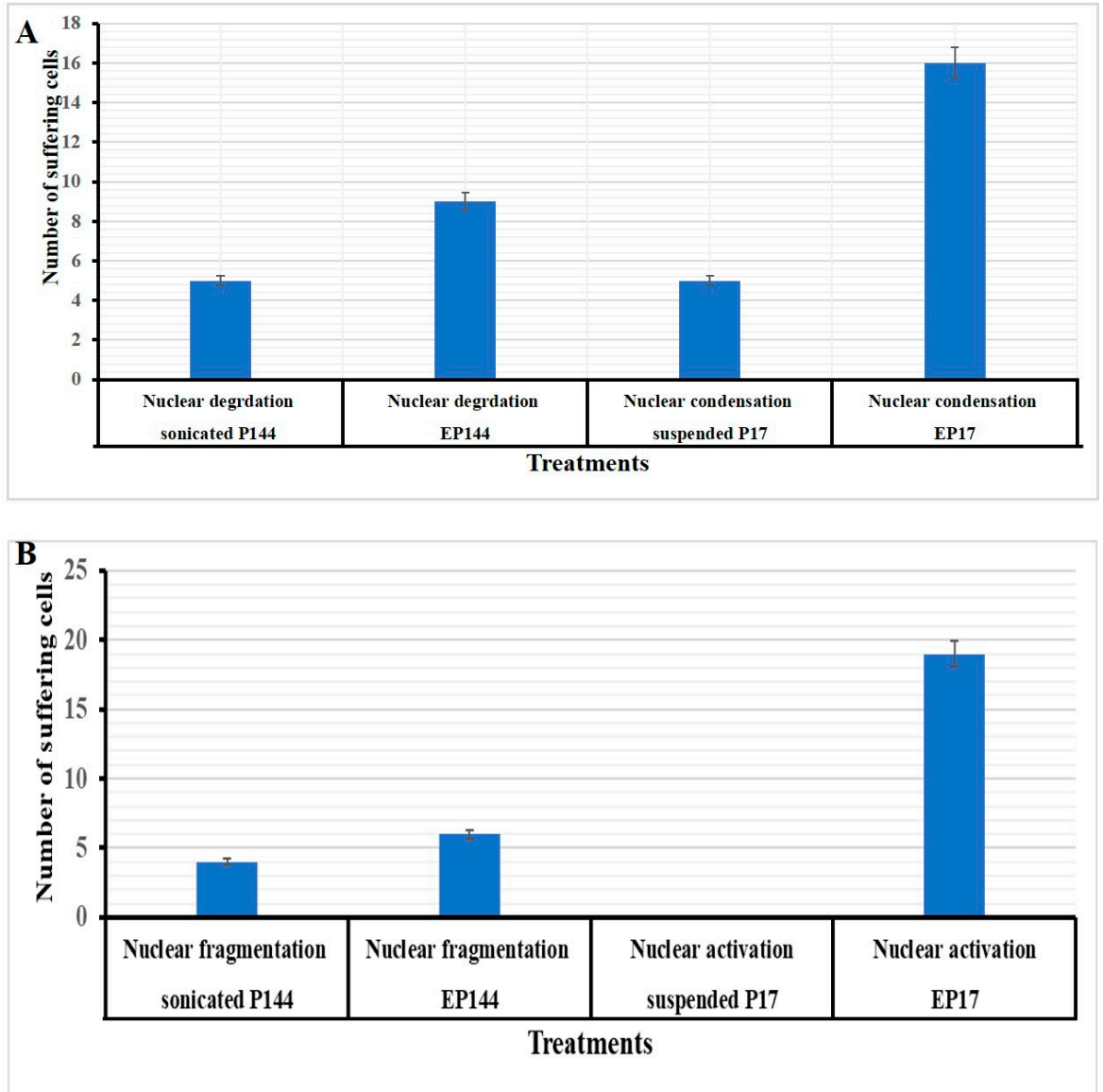

Figure 9. Quantification analysis of nuclear morphology after DAPI staining. (A) Hep3B cells exposed to encapsulated and non-encapsulated P17 and P144. (B) SNU449 cells exposed to encapsulated and non-encapsulated P17 and P144.

\subsection{Antiproliferative Effect of Encapsulated Peptides}

Crystal violet cell proliferation assay is a colorimetric method based on the use of crystal violet as a basic dye with avidity to nuclear structures. After binding and solubilization of the crystal violet, optical density measurements of extracted dye provide a measure of the relative number of viable cells. This test has the advantage that it is less time consuming, easier to perform and more objective [29].

Encapsulated peptides (P17 and P144) have an antiproliferative influence on human liver cancer cell lines (SNU449 and Hep3B) as shown by proliferation assay. Both encapsulated peptides (P17 and P144) inhibited the proliferation of human liver cancer cell lines in vitro in a dose-dependent manner. This inhibition was substantial in both cell lines after treatment, with significant differences from $10 \mu \mathrm{g} / \mathrm{mL}$ to $200 \mu \mathrm{g} / \mathrm{mL}$ in treated cells (Figure 10). Similar to our findings, it is reported that P17 and P144 induced antiproliferation effect against human lung cancer cell lines [44] and glioblastoma cell lines [45,46], respectively. On the other hand, Hep3B and SNU449 cell lines exhibited significant proliferation after their exposure to free capsules for $72 \mathrm{~h}$. 

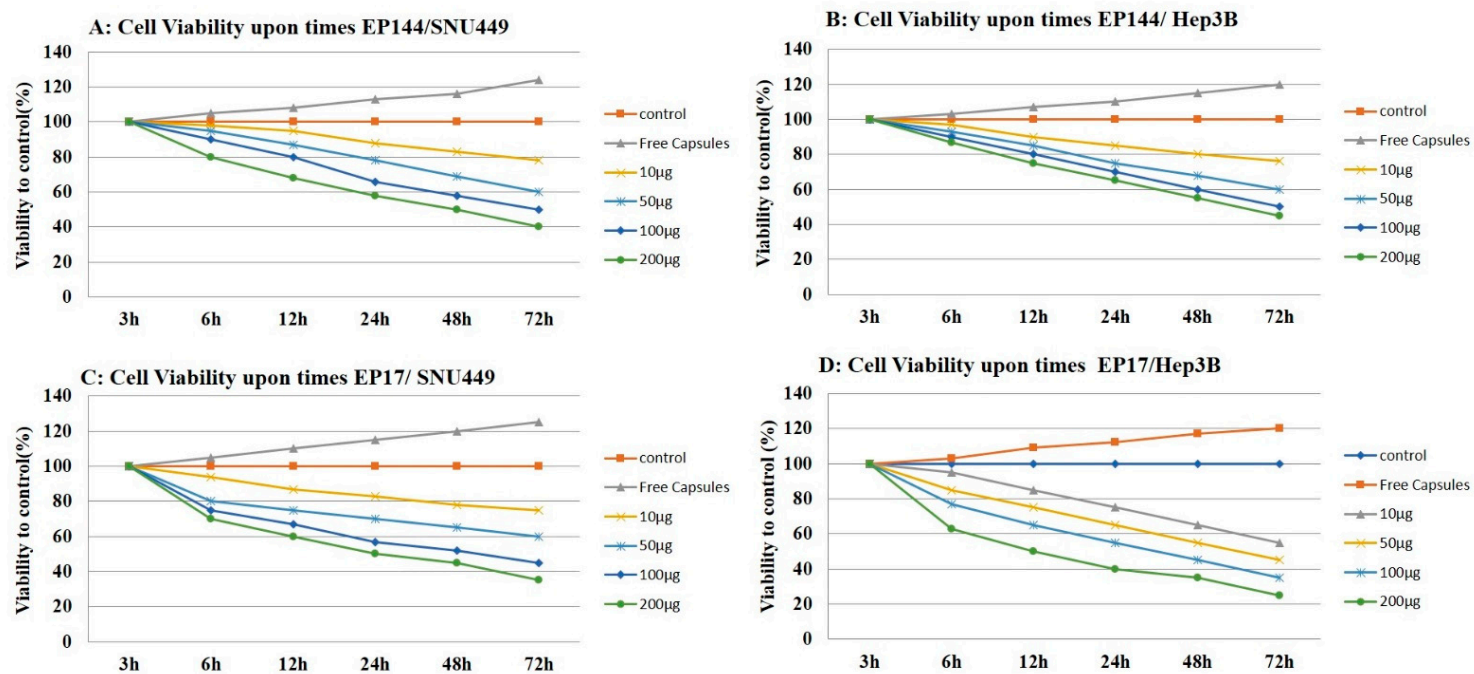

Figure 10. Cell proliferation assay. (A) Cell viability of SNU449 in a dose-dependent manner by using different concentrations of encapsulated P144. (B) Cell viability of Hep3B in a dose-dependent manner by using different concentrations of encapsulated P144. (C) Cell viability of SNU449 in a dose-dependent manner by using different concentrations of encapsulated P17. (D) Cell viability of Hep3B in a dose-dependent manner by using different concentrations of encapsulated P17.

\subsection{Effects of P144 and P17 on SMAD2 Phosphorylation}

SMADs are a group of encoded homologs mammalian protein identified by Small (Sma) and Mothers against dpp (Mad) genes that act as intracellular transcriptional factors [47]. SMAD2 and SMAD3 can be phosphorylated by the TGF $\beta$ RI after the direct binding of TGF $\beta$ ligand to its specific receptors (TGF $\beta$ RII). This enables them to form heteromeric complexes with SMAD4. This complex is translocated into the nucleus to regulate target genes [48]. Indeed, we next studied the response to TGF $\beta$ in terms of SMAD2 phosphorylation in both SNU449 and Hep3B cells. SNU449, but not Hep3B, presented basal SMAD2 phosphorylation. Both cell lines responded to external TGF $\beta$ significantly increasing phosphor-SMAD2 levels (Figure 11). Additionally, in the absence of external TGF $\beta 1$, SNU449 cells presented lower phosphorylation of SMAD2 after their exposure to P17, but not after their exposure to P144. This phosphorylation was not observed in Hep3B cells after their exposure to P17. However, slight phosphorylation was shown after their exposure to P144. In the presence of external TGF 31 , SNU449 cells increased the pSMAD2 signal after their exposure to P17 and P144. However, Hep3B presented lower phosphorylation of SMAD2 after their exposure to P17, but not after their exposure to P144. Interestingly, in the absence of the external TGF $\beta 1$, the encapsulated P17 and P144 caused a reduction of SMAD2 phosphorylation in both SNU449 and Hep3B cells. In presence of the external TGF $\beta 1$, encapsulated P17 clearly attenuated the level of SMAD2 phosphorylation in Hep3B cells and both encapsulated P144 and P17 attenuated SMAD2 phosphorylation in SNU449 cells. These results indicate that the encapsulation of P17 and P144 clearly shows advantages regarding their biological activity when compared with non-encapsulated peptides, particularly in the mesenchymal, more invasive, SNU449 cell line. 
Levels of phospho-SMAD2 relative to $\beta$ actin

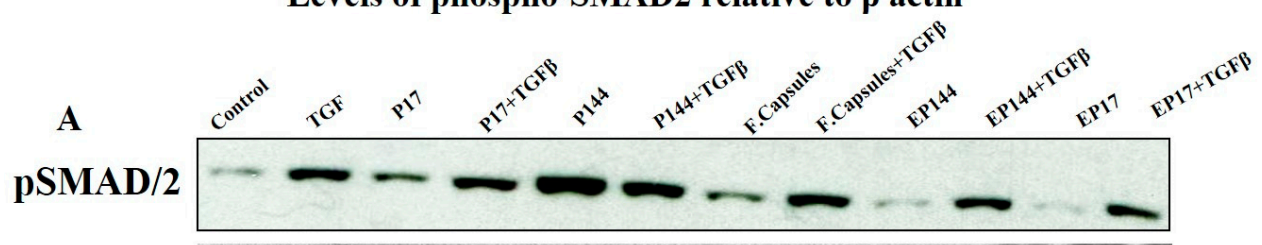

$\beta$ actin
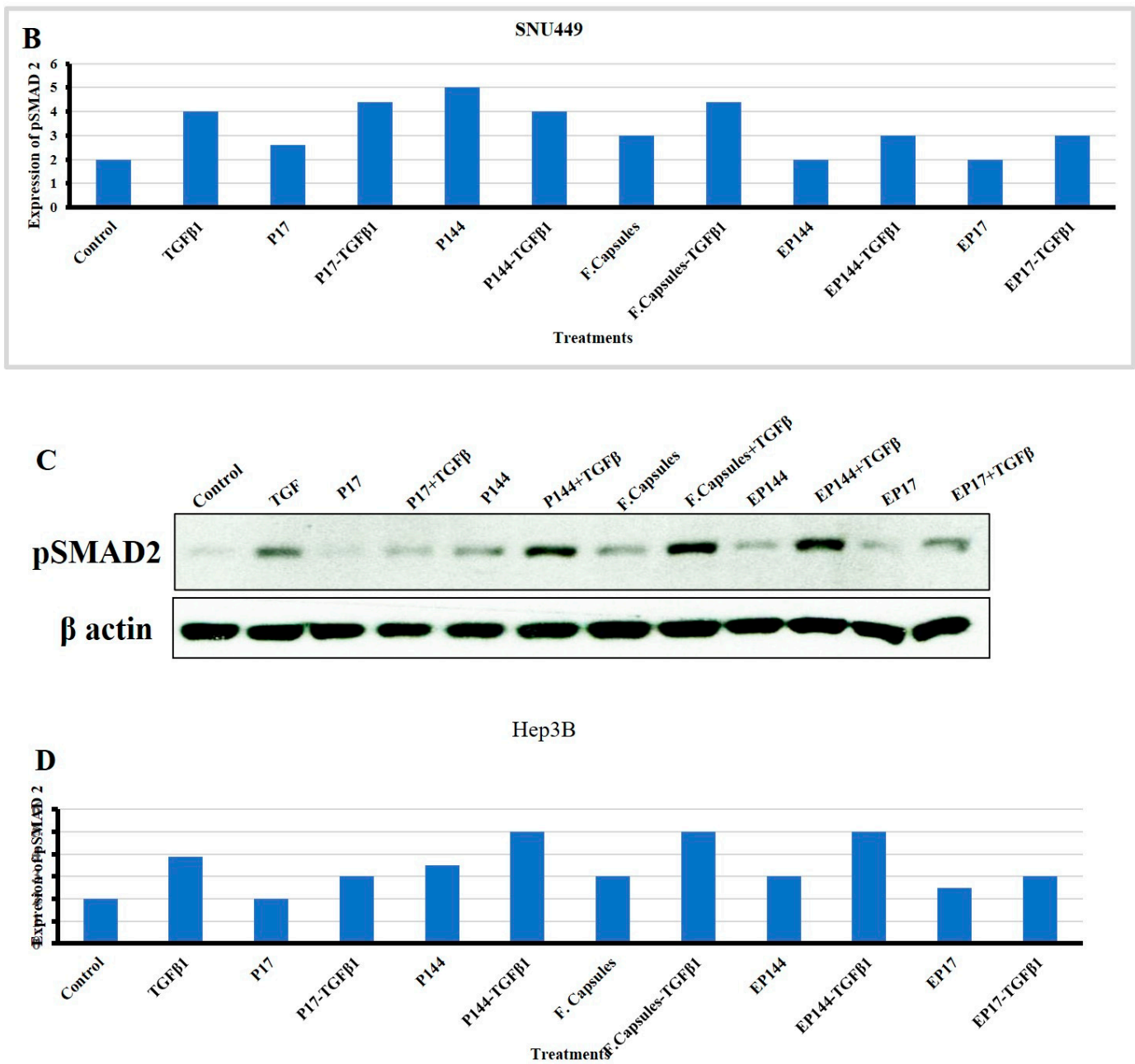

Figure 11. Evaluation of SMAD2 phosphorylation in SNU449 and Hep3B cells. (A,C) Western blot band of pSMAD2; beta-actin was analyzed as loading control. (B,D) Densitometric analysis of pSMAD2 levels after their exposure to several treatments for $6 \mathrm{~h}$.

\section{Discussion}

TGF $\beta 1$ inhibitory peptides have attracted much interest recently because of their ability to block the TGF $\beta 1$ signaling pathway [49], due to their possible binding to the extracellular region where the TGF $\beta 1$ ligand connects with its cellular receptors [30]. It is reported previously that the bulk of P144 can be separated into small particles by using sonication [30]. However, these small particles tend to be aggregated. This action may attribute their loss of the physicochemical interaction after sonication. Such action leads to the distribution of the electrostatic balance among these particles. For this reason, the small particles tend to be aggregated back after their separation. In the current work, we analyzed the possible separation of these particles by the next interaction with BSA. Hence, these particles 
are integrated into the moieties of BSA. This coupled interaction drives keeping the small particles of peptides under electrostatic balance and preventing their aggregation. The demonstration of rhodamine-labeled peptides exhibited a specific peak at $550 \mathrm{~nm}$ which is attributed to the main peak of pure rhodamine [32]. Increasingly, the second peak was shown at $490 \mathrm{~nm}$, which is similar to the main peaks of fluorescent isocyanate [50]. Perhaps, the central carbon atom of the chromophore is influenced by the ionic stress of the complex leading to a shift of both absorption and fluorescence emission related to the presence of tryptophan [35]. Rhodamine-labeled peptides advanced our knowledge concerning the physicochemical properties of these two peptides. For instance, their aggregation was localized even after their cellular uptake around the cytoplasmic region. This evidence was first detected by using fluorescence microscopy after their precipitation upon the surface of the slide (Figure 1G). In the same way, small particles of both peptides were compacted after their internalization with no equal distribution in the perinuclear region. To evaluate their aggregation, ImageJ analysis was used and it refers to the presence of an aggregation state in non-encapsulated peptides compared to encapsulated peptides (Supplementary Materials, Figure S1).

The protein-peptide assembly was further functionalized by protamine sulfate. This provides a novel strategy in terms of $\alpha$ helix titration resulting in turbidity [34]. Arginine rich protamine is responsible for this turbidity and it perhaps causes modification to the diameter of nanoparticles [51]. Furthermore, there is no published report observing immune-stimulatory side effects related to the use of protamine [51,52]. To increase their adhesion and cellular adsorption, this complex was further functionalized by folic acid conjugated carboxymethyl cellulose.

Apart from cellular adsorption, the DAPI staining noticeably revealed nuclear morphological changes in both SNU449 and Hep3B human liver cancer cell lines in terms of nuclear fragmentation, nuclear hypotrophy, nuclear condensation and cell structure loss. Accordingly, the present results proved significantly the potential efficient therapy of both encapsulated peptides against the analyzed cell lines. Similar to our results, P144 and P17 treatment resulted in significant inhibition at lung cancer cell lines [44] and the growth of glioblastoma cell lines [46] respectively. When analyzing the effects of encapsulated versus non-encapsulated peptides at the cellular level, we observed that the efficiency of the encapsulated peptides was remarkably higher in the SNU449 cells. We and other authors had previously demonstrated that the SNU449 cells show autocrine stimulation of the TGF $\beta$ pathway and respond to TGF- $\beta$ increasing Smad2/3 phosphorylation [53]. These cells are resistant to the suppressor effects of TGF $\beta$ [54] and respond to it undergoing EMT. Here, we show that encapsulated peptides (P17 and P144) induced significant inhibition of basal pSMAD2 in SNU449 cells when compared to non-encapsulated peptides. Additionally, pSMAD2 phosphorylation is considerably attenuated after TGF $\beta$ treatment. In summary, the transforming growth factor $\beta$ (TGF- $\beta$ ) signaling pathway consists of extracellular ligands (including the TGF- $\beta$-like group and BMP-like group). The TGF- $\beta$-like group generally phosphorylates SMAD2 and SMAD3, whereas the BMP-like group generally induces phosphorylation of SMAD1, SMAD5 and SAMD8 [55]. The activated R-SMADs form hetero-oligomeric complexes with Co-SMAD (SMAD4), which are translocated to the nucleus where they regulate the expression of target genes. In general, both pathways are translocated into the nucleus to translate the signal [56]. In this recent study, the phosphorylation of SMAD2 was studied using Western blot analysis. Additionally, nuclear alteration was distinguished.

\section{Conclusions}

In conclusion, the encapsulation of TGF $\beta$ inhibitory peptides (P17 and P144) has shown potential therapeutic inhibition to basal phospho-SMAD as a result of TGF- $\beta$ pathway regulation. It has proved clearly their ability to inhibit the autocrine TGF $\beta$ pathway and basal nuclear SMAD. However, SNU449 is one of the cell lines that is more responsive to those encapsulated by P17 and P144 is a mesenchymal, invasive HCC cell line that produces TGF $\beta$ autocrinally and is unresponsive to its suppressor effects. Additionally, rhodamine-labeled peptides enable researchers to follow nearly the localization of peptides inside cytoplasm after their cellular uptake. In the current studies and our 
previous studies indicated that encapsulation of TGF $\beta$ signaling pathway inhibitors may facilitate their delivery and overcome their cytotoxicity. Additionally, folic acid functionalized drug delivery systems enable them to reach and accumulate inside cancer cells [57-62].

Supplementary Materials: The following are available online at http://www.mdpi.com/1999-4923/12/5/421/s1, Figure S1: Fluorescence microscopy images for labelled P144, Scheme S1: (A): Folic Acid conjugated carboxymethyl cellulose. (B) Labelling carboxymethyl cellulose with FITC, Scheme S2: Fabrication of protein mucoadhesive targeted therapy.

Author Contributions: Formal analysis, M.E.K.; funding acquisition, S.L., I.F.; investigation and analysis, N.A.N.H.; methodology, N.A.N.H.; supervision, I.F., S.L. and M.E.K.; writing-original draft, N.A.N.H., revised by I.F. and S.L. All authors have read and agreed to the published version of the manuscript.

Funding: This work was supported by REA Research Grant n. PITN-GA-2012-316549 (IT LIVER) from the People Programme (Marie Curie Actions) of the European Union's Seventh Framework Programme (FP7/2007-2013). S.L. is supported by Progetto FISR-CNR "Tecnopolo di Nanotecnologia e Fotonica per la Medicina di Precisione"CUP B83B17000010001.

Acknowledgments: This work was supported by Institute of Nanoscience and Nanotechnology, Kafrelsheikh University, Egypt.

Conflicts of Interest: The authors declare no conflict of interest

\section{References}

1. David, C.J.; Massague, J. Contextual determinants of TGF-ß action in development, immunity and cancer. Nat. Rev. Mol. Cell Biol. 2018, 19, 419-435. [CrossRef] [PubMed]

2. Miyazawa, K.; Miyazono, K. Regulation of TGF- $\mathbb{B}$ family signaling by inhibitory SMADs. Cold Spring Harb. Perspect. Biol. 2017, 9, a022095.

3. Hanafy, N.A.; El Kemary, M. TGF $\beta 1$ as a Good and Bad Biological Molecule: Structure and Function. Biomed. J. Sci. Tech. Res. BJSTR 2019. [CrossRef]

4. Landén, N.X.; Li, D.; Ståhle, M. Transition from inflammation to proliferation: A critical step during wound healing. Cell. Mol. Life Sci. 2016, 73, 3861-3885.

5. Zhang, Y.; Alexander, P.B.; Wang, X.F. TGF- $B$ family signaling in the control of cell proliferation and survival. Cold Spring Harb. Perspect. Biol. 2017, 9, a022145. [CrossRef]

6. ten Dijke, P.; Arthur, H.M. Extracellular control of TGF-ß beta signalling in vascular development and disease. Nat. Rev. Mol. Cell Biol. 2007, 8, 857-869. [CrossRef]

7. Heldin, C.H.; Moustakas, A. Signaling receptors for TGF-B family members. Cold Spring Harb. Perspect. Biol. 2016, 8, a022053. [CrossRef]

8. Zarranz-Ventura, J.; Fernández-Robredo, P.; Recalde, S.; Salinas-Alamán, A.; Borrás-Cuesta, F.; Dotor, J.; García-Layana, A. Transforming growth factor-beta inhibition reduces progression of early choroidal neovascularization lesions in rats: P17 and P144 peptides. PLoS ONE 2013, 31, e65434. [CrossRef]

9. Murillo-Cuesta, S.; Rodríguez-de la Rosa, L.; Contreras, J.; Celaya, A.M.; Camarero, G.; Rivera, T.; Varela-Nieto, I. Transforming growth factor $\beta 1$ inhibition protects from noise-induced hearing loss. Front. Aging Neurosci. 2015, 7, 32.

10. Ezquerro, I.J.; Lasarte, J.J.; Dotor, J. A synthetic peptide from transforming growth factor $\beta$ type III receptor inhibits liver fibrogenesis in rats with carbon tetrachloride liver injury. Cytokine 2003, 22, 12-20. [CrossRef]

11. Dotor, J.; Lopez-Vazquez, A.B.; Lasarte, J.J.; Sarobe, P.; Garcia-Granero, M.; Riezu-Boj, J.I.; Martinez, A.; Feijoo, E.; Lopez-Sagaseta, J.; Hermida, J.; et al. Identification of peptide inhibitors of transforming growth factor beta 1 using a phage displayed peptide library. Cytokine 2007, 39, 106-115. [CrossRef] [PubMed]

12. Gil-Guerrero, L.; Dotor, J.; Huibregtse, I.J.; Casares, N.; Lopez-Vazquez, A.B.; Rudilla, F.; Riezu-Boj, J.I.; Lopez-Sagaseta, J.; Hermida, J.; Van Deventer, S.; et al. In vitro and in vivo down-regulation of regulatory Tcell activity with a peptide inhibitor of TGF-beta1. J. Immunol. 2008, 181, 126-135.

13. Santiago, B.; Gutierrez-Canas, I.; Dotor, J.; Palao, G.; Lasarte, J.J.; Ruiz, J.; Prieto, J.; Borras-Cuesta, F.; Pablos, J.L. Topical application of a peptide inhibitor of transforming growth factor-beta1 ameliorates bleomycin-induced skin fibrosis. J. Investig. Dermatol. 2005, 125, 450-455. [CrossRef] [PubMed] 
14. Kratz, F.; Müller-Driver, R.; Hofmann, I.; Drevs, J.; Unger, C. A novel macromolecular prodrug concept exploiting endogenous serum albumin as a drug carrier for cancer chemotherapy. J. Med. Chem. 2000, 43, 1253-1256. [CrossRef]

15. Llopiz, D.; Dotor, J.; Zabaleta, A.; Lasarte, J.J.; Prieto, J.; Borras-Cuesta, F.; Sarobe, P. Combined immunization with adjuvant molecules poly(I:C) and anti-CD40 plus a tumour antigen has potent prophylactic and therapeutic antitumor effects. Cancer Immunol. Immunother. 2008, 57, 19-29. [CrossRef] [PubMed]

16. Recalde, S.; Zarranz-Ventura, J.; Fernández-Robredo, P.; García-Gómez, P.J.; Salinas-Alamán, A.; Borrás-Cuesta, F.; Dotor, J.; García-Layana, A. Transforming growth factor- $\beta$ inhibition decreases diode laser-induced choroidal neovascularization development in rats: P17 and P144 peptides. Investig. Ophthalmol. Vis. Sci. 2011, 52, 7090-7097. [CrossRef] [PubMed]

17. Qiu, S.S.; Dotor, J.; Hontanilla, B. Effect of P144 ${ }^{\circledR}$ (Anti-TGF- $\beta$ ) in an "In Vivo" Human Hypertrophic Scar Model in Nude Mice. PLoS ONE 2015, 10, e0144489. [CrossRef]

18. Da Violante, G.; Zerrouk, N.; Richard, I.; Provot, G.; Chaumeil, J.C.; Arnaud, P. Evaluation of the cytotoxicity effect of dimethyl sulfoxide (DMSO) on Caco2/TC7 colon tumor cell cultures. Biol. Pharm. Bull. 2002, 25, 1600-1603. [CrossRef]

19. Hanafy, N.A.N. Encapsulation of cancer signalling pathway inhibitors as a protective way for healthy cells. Commentary. Med. Res. Innov. 2018. [CrossRef]

20. Soukupova, J.; Malfettone, A.; Hyroššová, P.; Hernández-Alvarez, M.I.; Peñuelas-Haro, I.; Bertran, E.; Junza, A.; Capellades, J.; Giannelli, G.; Yanes, O.; et al. Role of the Transforming Growth Factor- $\beta$ in regulating hepatocellular carcinoma oxidative metabolism. Sci. Rep. 2017, 7, 12486. [CrossRef]

21. American Type Culture Collection. Available online: www.lgcstandards-atcc.org (accessed on 5 November 2018).

22. Zhou, Q.Y.; Tu, C.Y.; Shao, C.X.; Wang, W.K.; Zhu, J.D.; Cai, Y.; Mao, J.Y.; Chen, W. GC7 blocks epithelial-mesenchymal transition and reverses hypoxia-induced chemotherapy resistance in hepatocellular carcinoma cells. Am. J. Transl. Res. 2017, 9, 2608-2617. [PubMed]

23. Hanafy, N.A.N.; El-Kemary, M.; Leporatti, S. Reduction diameter of $\mathrm{CaCO}_{3}$ crystals by using poly acrylic acid might improve cellular uptake of encapsulated curcumin in breast cancer. J. Nanomed. Res. 2018, 7, 235-239.

24. Hanafy, N.A.N.; Ferraro, M.M.; Gaballo, A.; Dini, L.; Tasco, V.; Nobile, C.; De Giorgi, M.L.; Carallo, S.; Rinaldi, R.; Leporatti, S. Fabrication and Characterization of ALK1fc-Loaded Fluoro-Magnetic Nanoparticles Rods for Inhibiting TGF $\beta 1$ in HCC. RSC Adv. 2016, 6, 48834-48842. [CrossRef]

25. Hanafy, N.A.N.; El-Kemary, M.; Leporatti, S. Mucoadhesive curcumin crosslinked carboxy methyl cellulose might increase inhibitory efficiency for liver cancer treatment. Mater. Sci. Eng. C 2020, in press.

26. Safer, A.M.; Sen, A.; Hanafy, N.A.; Mousa, S.A. Quantification of the healing effect in hepatic fibrosis induced by Chitosan Nano-encapsulated Green Tea in Rat Model Studied-At Ultrastructural level. J. Nanosci. Nanotechnol. 2015, 15, 1-7.

27. Hanafy, N.A.; Nobile, C.; De Giorgi, M.L.; Ran, B.; Cao, Y.; Giannelli, G.; Leporatti, S. LY2157299-Loaded Carriers Inhibiting Wound Healing in Hepatocellular Carcinoma. J. Biotech. 2014, 185S, S18-S36. [CrossRef]

28. Hanafy, N.A.N.; De Giorgi, M.L.; Nobile, C.; Giannelli, G.; Quarta, A.; Leporatti, S. P0253: Inhibition of glycolysis by using nano lipid bromopyruvic chitosan carrier is a promising tool to prevent HCC invasiveness. J. Hepatol. 2015, 62, S401. [CrossRef]

29. Chiba, K.; Kawakami, K.; Tohyama, K. Simultaneous evaluation of cell viability by neutral red, MTT and crystal violet staining assays of the same cells. Toxicol. Vitro 1998, 12, 251-258. [CrossRef]

30. Hanafy, N.A.N.; Quarta, A.; Di Corato, R.; Dini, L.; Nobile, C.; De Giorgi, M.L.; Tasco, V.; Carallo, S.; Cascione, M.; Rinaldi, R.; et al. Encapsulation of SHT-DNA, SIRNA and polypeptide -17 inside Hybrid polymeric nano-protein folic acid (HPNP-FA) carriers as targeted TGF beta inhibitor for Hepatocellular carcinoma. J. Hepatol. 2016, 64, S425-S630. [CrossRef]

31. Jang, C.W.; Chen, C.H.; Chen, C.C.; Chen, J.; Su, Y.H.; Chen, R.H. TGF- $\beta$ induces apoptosis through Smad-mediated expression of DAP-kinase. Nat. Cell Biology 2002, 4, 51-58. [CrossRef]

32. Beija, M.; Afonso, C.A.M.; Martinho, J.M.G. Synthesis and applications of Rhodamine derivatives as fluorescent probes. Chem. Soc. Rev. 2009, 38, 2410-2433. [CrossRef] [PubMed]

33. Parodi, A.; Miao, J.; Soond, S.M.; Rudzińska, M.R.; Zamyatnin, A.A. Albumin Nanovectors in Cancer Therapy and Imaging. Biomolecules 2019, 9, 218. [CrossRef] [PubMed] 
34. Scheicher, B.; Lorenzer, C.; Gegenbauer, K.; Partlic, J.; Andreae, F.; Kirsch, A.H.; Rosenkranz, A.R.; Werzer, O.; Zimmer, A. Manufacturing of a Secretoneurin Drug Delivery System with Self-Assembled Protamine Nanoparticles by Titration. PLoS ONE 2016, 11, e0164149. [CrossRef] [PubMed]

35. Piston, D.W.; Kremers, G.J. Fluorescent protein FRET: The good, the bad and the ugly. Trends Biochem. Sci. 2007, 32, 407-414. [CrossRef] [PubMed]

36. Teale, F.W.J.; Weber, G. Ultraviolet fluorescence of the aromatic amino acids. Biochem. J. 1957, 65, 476-482. [CrossRef]

37. Junghans, M.; Kreuter, J.; Zimmer, A. Antisense delivery using protamine-oligonucleotide particles. Nucleic Acids Res. 2000, 28, e45. [CrossRef]

38. Kubista, M.; Aakerman, B.; Norden, B. Characterization of interaction between DNA and 4', 6-diamidino-2-phenylindole by optical spectroscopy. Biochemistry 1987, 26, 4545-4553. [CrossRef]

39. Barcellona, M.L.; Favilla, R.; Von Berger, J.; Avitabile, M.; Ragusa, N.; Masotti, L. DNA-4'-6-diamidine-2-phenylindole interactions: A comparative study employing fluorescence and ultraviolet spectroscopy. Arch. Biochem. Biophys. 1986, 250, 48-53. [CrossRef]

40. Kntayya, S.B.; Ibrahim, D.M.; Ain, M.N.; Iori, R.; Ioannides, C.; Abdull Razis, A.F. Induction of Apoptosis and Cytotoxicity by Isothiocyanate Sulforaphene in Human Hepatocarcinoma HepG2 Cells. Nutrients 2018, 10, 718. [CrossRef]

41. Estandarte, A.K.; Botchway, S.; Lynch, C.; Yusuf, M.; Robinson, I. The use of DAPI fluorescence lifetime imaging for investigating chromatin condensation in human chromosomes. Sci. Rep. 2016, 16, 31417. [CrossRef]

42. Gallo-Oller, G.; Vollmann-Zwerenz, A.; Melendez, B.; Rey, J.; Hau, P.; Dotor, J.; Castresana, J. P144, a Transforming Growth Factor beta inhibitor peptide, generates antitumoral effects and modifies SMAD7 and SKI levels in human glioblastoma cell lines. Cancer Lett. 2016, 381, 67-75. [CrossRef] [PubMed]

43. Llopiz, D.; Dotor, J.; Casares, N.; Bezunartea, J.; Díaz-Valdés, N.; Ruiz, M.; Aranda, F.; Berraondo, P.; Prieto, J.; Lasarte, J.J.; et al. Peptide inhibitors of transforming growth factor-beta enhance the efficacy of antitumor immunotherapy. Int. J. Cancer 2009, 125, 2614-2623. [CrossRef] [PubMed]

44. Zhang, J.; Pan, Y.; Liao, D.; Tang, J.; Yao, D. Peptide 17, an inhibitor of YAP/TEAD4 pathway, mitigates lung cancer malignancy. Trop. J. Pharm. Res. 2018, 17, 1256. [CrossRef]

45. Upadhyay, A.; Moss-Taylor, L.; Kim, M.J.; Ghosh, A.C.; O'Connor, M.B. TGF- $\beta$ family signaling in drosophila. Cold Spring Harb. Perspect. Biol. 2017, 9, a022152. [CrossRef]

46. Savage-Dunn, C.; Padgett, R.W. The TGF $\beta$ family in caenorhabditis elegans. Cold Spring Harb. Perspect. Biol. 2017, 9, a022178. [CrossRef]

47. Hao, Y.; Baker, D.; ten Dijke, P. TGF $\beta$-Mediated Epithelial-Mesenchymal Transition and Cancer Metastasis. Int. J. Mol. Sci. 2019, 20, 2767. [CrossRef]

48. Hanafy, N.A.N.; Quarta, A.; Di Corato, R.; Dini, L.; Nobile, C.; Tasco, V.; Carallo, S.; Cascione, M.; Malfettone, A.; Soukupova, J.; et al. Hybrid polymeric-protein nano-carriers (HPPNC) for targeted delivery of TGF $\beta$ inhibitors to hepatocellular carcinoma cells. J. Mater. Sci. Mater. Med. 2017, 28, 120. [CrossRef]

49. Hanafy, N.A.; De Giorgi, M.L.; Nobile, C.; Rinaldi, R.; Leporatti, S. Control of Colloidal $\mathrm{CaCO}_{3}$ suspension by using biodegradable polymers during fabrication. Beni-Suef Univ. J. Basic Appl. Sci. 2015, 4, 60-70.

50. Chaganti, L.K.; Venkatakrishnan, N.; Bose, K. An efficient method for FITC labelling of proteins using tandem affinity purification. Biosci. Rep. 2018, 38. [CrossRef]

51. Takikawa, M.; Nakamura, S.; Ishihara, M.; Takabayashi, Y.; Fujita, M.; Hattori, H. Improved angiogenesis and healing in crush syndrome by fibroblast growth factor-2 containing low-molecular-weight heparin (Fragmin)/protamine nanoparticles. J. Surg. Res. 2015, 196, 247-257. [CrossRef]

52. Mayer, G.; Vogel, V.; Weyermann, J.; Lochmann, D.; van den Broek, J.A.; Tziatzios, C. Oligonucleotideprotamine- albumin nanoparticles: Protamine sulfate causes drastic size reduction. J. Control. Release 2005, 106, 181-187. [CrossRef] [PubMed]

53. Malfettone, A.; Soukupova, J.; Bertran, E.; Crosas-Molist, E.; Lastra, R.; Fernando, J.; Koudelkova, P.; Rani, B.; Fabra, Á; Serrano, T.; et al. Transforming growth factor- $\beta$-induced plasticity causes a migratory stemness phenotype in hepatocellular carcinoma. Cancer Lett. 2017, 392, 39-50. [CrossRef] [PubMed] 
54. Bertran, E.; Crosas-Molist, E.; Sancho, P.; Caja, L.; Lopez-Luque, J.; Navarro, E.; Egea, G.; Lastra, R.; Serrano, T.; Ramos, E.; et al. Overactivation of the TGF- $\beta$ pathway confers a mesenchymal-like phenotype and CXCR4-dependent migratory properties to liver tumor cells. Hepatology 2013, 58, 2032-2044. [CrossRef] [PubMed]

55. Hata, A.; Chen, Y.G. TGF- $\beta$ signaling from receptors to smads. Cold Spring Harb. Perspect. Biol. 2016, 8, a022061. [CrossRef] [PubMed]

56. Zheng, S.; Long, J.; Liu, Z.; Tao, W.; Wang, D. Identification and Evolution of TGF- $\beta$ Signaling Pathway Members in Twenty-Four Animal Species and Expression in Tilapia. Int. J. Mol. Sci. 2018, 19, 1154. [CrossRef] [PubMed]

57. Hanafy, N.A.; Dini, L.; Citti, C.; Cannazza, G.; Leporatti, S. Inhibition of Glycolysis by Using a Micro/Nano-Lipid Bromopyruvic Chitosan Carrier as a Promising Tool to Improve Treatment of Hepatocellular Carcinoma. Nanomaterials 2018, 8, 34. [CrossRef]

58. Hanafy, N.A.; De Giorgi, M.L.; Nobile, C.; Cascione, M.; Rinaldi, R.; Leporatti, S. CaCO3 rods as chitosan polygalacturonic acid carriers for brompyruvic acid delivery. Sci. Adv. Mater. 2016, 8, 514-523. [CrossRef]

59. Hanafy, N.A.N. The growth of hepatocellular carcinoma can be inhibited by encapsulation of TGF $B 1$ antagonists. SL Pharmacol. Toxicol. 2018, 1, 112.

60. Hanafy, N.A.N.; El-Kemary, M.; Leporatti, S. Understanding TGF $\beta 1$ signalling pathway is well strategy to use its encapsulated antagonist as nano therapeutic molecules. Transl. Sci. 2018, 2018.

61. Hanafy, N.A.N. Glycolysis is a promising target for encapsulation nano-therapeutic molecules against cancer cells. Commentary. Integr. Cancer Sci. Therap. 2017, 2017.

62. Hanafy, N.A.N. Development and Production of Multifunctional Bio-Nano-Engineered Drug Delivery Systems Loaded by TGF Inhibitors for Delivering into Hepatocellular Carcinoma Cells. Ph.D. Thesis, Salento University Italy, Lecce, Italy, 2017.

(C) 2020 by the authors. Licensee MDPI, Basel, Switzerland. This article is an open access article distributed under the terms and conditions of the Creative Commons Attribution (CC BY) license (http://creativecommons.org/licenses/by/4.0/). 